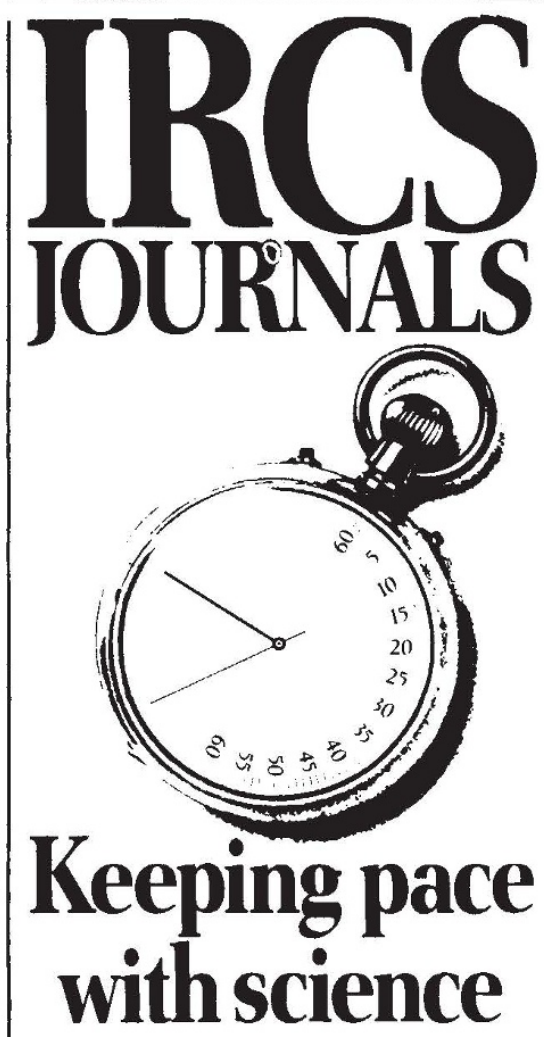

IRCS Medical Science

St. Leonard's House

St. Leonardgate,

Lancaster, U.K.

A member of Elsevier Science Publishers

\section{SCIENTIFIC BOOKSHOP}

H.K. LEWIS can supply works in all branches of Pure and Applied Science. Catalogues on request. Please state interests.

\section{SCIENTIFIC \\ LENDING LIBRARY}

Annual Subscription from $\mathbf{f 8 . 5 0}$ (Available in U.K. only)

Reduced rates for multiple subscriptions.

\section{Prospectus post free on request.}

Quarterly List of New Books and new editions added to the Library sent post free to subscribers regularly.

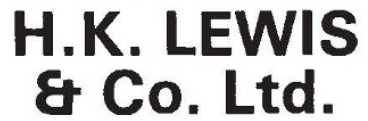

136 GOWER STREET, LONDON, WC1E 6BS (subsistence) requirements and higher optimal intakes existed? And surely the tenacity with which they clung to the idea of a special role for protein related to the social value of protein food such as meat.

But for all that Professor Guggenheim's book does not provide any solutions to such problems, it makes it clear that they exist to be solved. I hope the fluency and clear erudition of this book will encourage others to read it, to consider the same questions and, perhaps, to provide some answers.

John Rivers is a Lecturer in the Department of Human Nutrition at the London School of Hygiene and Tropical Medicine, University of London.

\section{Hectares for whom?}

\section{John Andrews}

Farming and Wildlife. By Kenneth Mellanby. Pp.178. ISBN 0-00-219239-X. (Collins: 1981.) £9.50. Countryside Conservation: The Protection and Management of Amenity Ecosystems. By Bryn Green. Pp.249. ISBN hbk 0-04-719001-9; ISBN pbk 0-04-719002-7. (George Allen \& Unwin: 1981.) Hbk £13, \$35; pbk £6.95, $\$ 17.95$.

SINCE prehistoric times, agriculture has been the major modifier of the world's terrestrial habitats; even the marine environment has been affected by the run-off of silt, organic nutrients and latterly of agrochemicals. In those countries where there is an active nature conservation lobby, relations with farming interests have become progressively more strained over the past 30 years as modern agricultural techniques have made rapid inroads into wildlife communities which had long coexisted with traditional farming methods. Inevitably, both sides have tended to misrepresent the situation to some degree and Professor Kenneth Mellanby's Farming and Wildlife provides a valuably calm and dispassionate appraisal of the effects of each on the other.

The opening chapters of the work deal in general terms with the impact of man on Britain's natural habitats and wildlife over the last 7,000 years, and more specifically with the effects of changing methods in arable farming, grassland management and livestock production since 1945 . Greatly increased productivity from existing farmland has been won at the expense of a vast reduction in the population of until recently common and widespread wildlife, of which our native flowers and butterflies are perhaps the most regretted loss. At the same time, the profitability of farming and the incentives of grant aid have brought much marginal land into intensive production, severely reducing many species which were already rare. The middle section of the book looks in some detail at the features of typical lowland farms over which most public concern has been expressed - the soil itself; hedges and trees; and ponds, rivers and marshes.

Thus far the book contains much that will come as news to farmers who are often profoundly ignorant about the wildlife on the land and their own effects on it. By contrast, the final section contains much to inform the concerned but often equally illinformed public about pests and pesticides, diseases of livestock and about field sports, which indirectly contribute to the retention of habitats and hence of wildlife in the countryside.

Farming and Wildlife is well illustrated and readable. No doubt conservationists will read it. The question is, will farmers?

Professor Mellanby deliberately eschews the political aspects of farming and wildlife, in particular the questions of whether increased agricultural output is economically justified and whether society should be able to control rural land use change where public loss of amenity is significant. However, these questions are examined with skill and relish by Bryn Green in Countryside Conservation.

It is timely that conservation, which has become an increasingly complex and skilled profession, now has its first textbook, and entirely apposite, given that the conservation movement is fighting desperately for what it believes in, that the textbook should also be a confident and wellargued assertion of its case.

Part 1 is devoted to conservation concepts, the impact of man on his environment and the development of conservation in Britain. In Part 2 the author examines the characteristics of natural ecosystems and explains the impact of land use change on all our major habitat types: agriculture figures largely, but forestry, industrial and urban development, recreational impact and pollution are given comparably thorough coverage. Conservation considerations aside, one is reminded again that land use management in Britain, where every hectare counts, is in appalling disarray, with blinkered state agencies each pursuing its own special interest regardless of the general good.

The concluding section of the book examines the present methods for selection and protection of land of conservation importance, and argues that a new approach is required if we are to save the remaining areas of scientific importance and the natural beauty of the countryside.

A welcome departure from the somewhat petulant "smock's and windmills" approach of some recent writers, Bryn Green's book contains much to instruct and to inspire a hard-headed approach to the massive problems which the conservation movement now faces.

John Andrews is Head of Conservation Planning at the Royal Society for the Protection of Birds, Sandy, Bedfordshire. 